\title{
A Comparative Study on Socio-Personal and Economic Profile of Contract Farmers and Non-Contract Farmers in Jammu
}

\author{
Parvani Sharma*, Rakesh Nanda and Yudhishther Singh Bagal
}

Division of Agriculture Extension Education, SKUAST-Jammu, J\&K, India

*Corresponding author

\begin{tabular}{|c|}
\hline Keywords \\
\hline $\begin{array}{l}\text { Contract farming, } \\
\text { Livelihood, Socio- } \\
\text { personal and economic } \\
\text { profile, Land holding }\end{array}$ \\
\hline Article Info \\
\hline $\begin{array}{l}\text { Accepted: } \\
\text { 06 July } 2018 \\
\text { Available Online: } \\
10 \text { August } 2018\end{array}$ \\
\hline
\end{tabular}

A B S T R A C T

Contract farming in simple terms, is an arrangement in which a firm purchases the crop produce from farmers under certain terms and conditions regarding price, quantity and quality. To find the socio-personal and economic profile of contract and non- contract farmers this study was conducted. Random sampling technique was used for selecting the sample of contract and non-contract farmers. The total sample size was 100 contract farmers and 100 non-contract farmers. Thus, making a total sample of 200. Interview schedule was used for the collection of data. The significance difference was observed between the contract farmers and non-contract farmers with respect to unirrigated land $(\mathrm{t}=$ 4.254, $\mathrm{p}=0.05)$, family type $(\mathrm{t}=2.830, \mathrm{p}=0.01)$, occupation $(\mathrm{Z}=2.388, \mathrm{p}=0.016)$. Agriculture was the main source of livelihood for the contract farmers as compare to noncontract farmers. Majority of the contract farmers were illiterate, in comparison to noncontract farmers. But the contract farmers have more experience of agriculture than that of the non-contract farmers. There was significant association between the contract farmers and non-contract farmers in terms of the farm inventory possessed by them like cattle shed, storage facilities, milch animals, farm implements and machine. The gross value of the farm inventory of contract farmers was more than that of non-contract farmers. Television was the major source of information for both the contract and non-contract farmers followed by radio and newspaper. As compare to contract farmers, the non-contract farmers were not socially active as they rarely visit to the agriculture department, KVK, input dealer etc.

\section{Introduction}

In an age of market liberalization, globalization and expanding agribusiness, small farmer will find difficulty in fully participating in the market economy. This leads to the drift of population to urban areas that is being witnessed almost everywhere. Many attempts by governments and development agencies are taken to check this drift have tended to emphasize the identification of 'income generation' activities for rural people. But there is relatively little evidence that such attempts are successful. This is because the necessary backward and forward market linkages are rarely in place. i.e. rural farmer and small scale entrepreneurs lack both reliable and cost-efficient inputs such as extension advice, mechanization services, seeds, fertilizers and credit, and 
guaranteed and profitable market for their output. Well organized contract farming however, provides such linkages, and an important way in which smaller producer can farm in a commercial manner. Similarly, it also provides investors with the opportunity to guarantee a reliable source of supply from the perspectives of both quality and quantity. In the era of globalization the concept of contract farming is one of the effective way to coordinate and promote production and marketing in agriculture. Contract farming is the contractual arrangement between farmers and a company, whether oral or written, specifying one or more conditions of production and or marketing (Roy, 1963). Sharma (2008) in his study concludes that the contract farming has a positive impact on crop-productivity and farm income. The socioeconomic factors that influenced participation in contract farming were education, age, farm size, source of off-farms income and membership to an organization. Similarly, Pandit et al., (2009) discussed about the socioeconomic profile of the potato growers of Sankrail of Howrah district. The results of the study portrayed that contract farmers were more experienced and have more years of schooling. The social participation was significantly more in case of contract farmers. Social participation, i.e., member or office bearer of co-operative societies, religious bodies, political parties, etc. helps farmers to venture out for new scheme of production like contract farming. Likewise to compare the socio-personal and economic profile of contract farmers and non-contract farmers of Basmati rice in Jammu region this study was planned.

\section{Materials and Methods}

The contract farming was prevalent only in Basmati-370 in Jammu division of Jammu and Kashmir State. Therefore, Jammu division and Basmati-370 were selected purposively as study area and study crop, respectively. A list of districts which cultivate rice under contract farming was prepared in consultation with Private Agency (Sarveshwar Overseas Mills). Three villages from each district having maximum number of contract farmers were selected purposively for the study. Thus, in all six villages were selected from the two selected districts. From the selected villages, the list of contract farmers was prepared. From the total list of 584 respondents, 100 contract farmers were selected randomly for the study and same number of non-contract farmers having similar land holdings was selected from the same villages randomly without replacement for the present study. So, in this way a sample of 100 contract farmers and 100 non-contract farmers of basmati rice in Jammu division was taken for the study. Interview schedule was constructed for the collection of the data. The research schedule was pre-tested in non-sampled area to find out the ambiguity, and weakness in the items of the schedule.

\section{Results and Discussion}

\section{Socio-personal and economic profile of the respondents}

Socio-personal and economic profile of the respondents of contract and non-contract farmers included age, education, caste, land holdings, family size and farming experience (Table 1).

The mean age of contract farmers was $\mathbf{5 2 . 1 6}$ years, whereas, it was 49.71 years in case of non-contract farmers (Table 1). The difference between the mean age of contract and noncontract farmers was not statistically significant. The findings of the study indicated that majority of the contract and non-contract farmers were in age-group of 45-60 years. This may be due to insistence or advice of young members of the family or by following the young farmers of the neighborhood to 
adopt contract farming. However, the findings of the study are in line with Arumugam and Shamsudin (2013) who stated that majority of the contract farmers were of middle agegroup. The mean number of formal schooling years completed by the contract farmers was 6.22 and in case of non-contract farmers it was 5.6 years. The difference in mean number of formal schooling years between contract and non-contract farmers was not statistically significant. The data depicted that $36 \%$ of the contract farmers were illiterate, followed by below primarily school education (16\%), primary education $(15 \%)$, middle $(21 \%)$ and $12 \%$ of them had higher secondary level of education. In case of non-contract farmers about one third of $(34 \%)$ of them were matriculates, followed by $21 \%$ of them were illiterate, $20 \%$ were middle passed, $10 \%$ were below primary educated and $9 \%$ were primary educated. For contract farmers $62 \%$ of the respondents belonged to general category, followed by schedule caste $(27 \%)$ and schedule tribes $(6 \%)$. In case of non-contract farmers, majority $(63 \%)$ of them were from general category, $35 \%$ of them were schedule caste and least were schedule tribe (2\%). Statistically there was no association between the contract and non-contract farmers.

Table 1 also shows that $59 \%$ of the contract farmers were small farmers having a land holding of 1-2 hectare followed by $23 \%$ of the contract farmers were marginal having a land holding of less than 1 hectare and only $18 \%$ of them were semi-medium having a land holding of 2-4 hectare. Whereas, in case of non-contract farmers, $18 \%$ of the respondents were small having a land holding of 1-2 hectare, followed by $73 \%$ of them was marginal having a land holdings of less than 1 hectare and least i.e. $9 \%$ were categorized into semi-medium having a land holding of 2-4 hectare. The overall data shows that the operational land holding of contract farmers was 1.45 hectare and in case of non-contract farmers was 1.28 hectare. The mean difference between the average land holding of contract and non-contract farmers were statistically non-significant. Hence, contract and noncontract farmers were matching at this parameter.

The data also revealed that average irrigated area of contract farmers was 1.07 hectare, but it was less in case of non-contract farmers i.e. 1.16 hectare. The mean difference between irrigated land holding of contract and noncontract farmers was statistically nonsignificant. Further, in case of unirrigated land, contract farmers had unirrigated area of 0.38 hectare and for non-contract farmers it was 0.12 hectare, and it was statistically significant. In case of non-contract farmers the average family size was 6.67 individuals per households. The average number of adults for contract farmers was 4.07 individuals per households and in case of non-contract farmers it was 6.67 individuals per households. The difference between the average number of adults for contract and non-contract farmers was statistically nonsignificant.

The data in the table 1 depicts that $74 \%$ of the contract farmers were exclusively dependent on agriculture and $26 \%$ of sampled contract farmers reported agriculture as a subsidiary occupation. Whereas in case of non-contract farmers $58 \%$ of the respondents were to be reported agriculture as a primary occupation while $42 \%$ of them reported agriculture as secondary occupation. The difference between the occupation of the contract and noncontract was statistically significant.

An average experience of contract farmers was 31.07 years and incase of non-contract farmers it was 28.07 years. The difference between average farming experience of contract and non-contract farmers was statistically insignificant. 
Table.1 Socio-personal profile of the contract and non-contract farmers

\begin{tabular}{|c|c|c|c|c|}
\hline Parameters & $\begin{array}{c}\text { Contract Farmer } \\
(\mathbf{n}=100)\end{array}$ & $\begin{array}{l}\text { Non-Contract } \\
\text { Farmer }(n=100)\end{array}$ & $\begin{array}{c}\text { Absolute } \\
\text { difference value }\end{array}$ & $\begin{array}{l}\text { Statistics (P- } \\
\text { value) }\end{array}$ \\
\hline Mean age(years) & $52.16( \pm 10.57)$ & $49.71( \pm 10.36)$ & 2.45 & $\mathrm{t}=0.346^{\mathrm{NS}}(0.726)$ \\
\hline Upto 45 years (\% farmers) & 31 & 32 & 1 & \\
\hline $45-60$ years (\% farmers) & 39 & 49 & 10 & \\
\hline 60 years \& above ( $\%$ farmers) & 30 & 19 & 11 & \\
\hline $\begin{array}{l}\text { Mean education } \\
\text { (Formal number of schooling } \\
\text { years completed) }\end{array}$ & $6.22( \pm 3.8)$ & $5.6( \pm 3.03)$ & 0.62 & $\mathrm{t}=0.891^{\mathrm{Ns}}(0.373)$ \\
\hline \multicolumn{5}{|l|}{ Education level (\%farmers) } \\
\hline i) Illiterate & 36 & 21 & 8 & \\
\hline ii) Below Primary & 16 & 10 & 14 & \\
\hline iii) Primary & 15 & 9 & 0 & \\
\hline iv) Middle & 21 & 20 & 10 & \\
\hline v) Matriculate & 12 & 34 & 14 & \\
\hline vi) Higher secondary & 0 & 6 & 2 & \\
\hline \multicolumn{5}{|l|}{ Caste (\% farmers) } \\
\hline i) General & 67 & 63 & 4 & \\
\hline ii) $\mathrm{SC}$ & 27 & 35 & 8 & \\
\hline iii) $\mathrm{ST}$ & 6 & 2 & 4 & \\
\hline iv) $\mathrm{OBC}$ & 0 & 0 & 0 & \\
\hline \multicolumn{5}{|l|}{$\begin{array}{l}\text { Categorization of farm size } \\
\text { (\% farmers) }\end{array}$} \\
\hline i) Marginal farmers $(<1 \mathrm{ha})$ & 23 & 73 & 11 & \\
\hline ii) Small-farmers (1-2 ha) & 59 & 18 & 2 & \\
\hline iii) Semi-medium (2-4 ha) & 18 & 9 & 13 & \\
\hline $\begin{array}{l}\text { Average operational land } \\
\text { holding(ha) }\end{array}$ & $1.45( \pm 0.42)$ & $1.28( \pm 0.38)$ & 0.04 & $\mathrm{t}=0.350^{\mathrm{Ns}}(0.726)$ \\
\hline $\begin{array}{l}\text { Area under irrigation } \\
\text { (in ha) }( \pm S D)\end{array}$ & $1.07( \pm 0.43)$ & $1.16( \pm 0.32)$ & 0.09 & $\mathrm{t}=0.202^{\mathrm{NS}}(0.841)$ \\
\hline Unirrigated area (in ha) & $0.38( \pm 2.00)$ & $0.12( \pm 0.25)$ & 0.26 & $\mathrm{t}=4.254 *(0.001)$ \\
\hline \multicolumn{5}{|l|}{ Family type (\%) } \\
\hline i) Nuclear & 59 & 39 & 20 & $\mathrm{Z}=2.830 *(0.001)$ \\
\hline ii) Joint & 41 & 61 & 20 & $\mathrm{Z}=2.830 *(0.001)$ \\
\hline Average family size & 5.48 & 6.62 & 114 & - \\
\hline $\begin{array}{l}\text { Average number of adults in } \\
\text { a family }\end{array}$ & $4.07( \pm 1.93)$ & $4.1( \pm 1.53)$ & 0.03 & $\mathrm{t}=0.121^{\mathrm{Ns}}(0.904)$ \\
\hline Average number of children & $1.41( \pm 0.66)$ & $2.52( \pm 1.47)$ & 1.11 & $\mathrm{t}=6.08 *(0.001)$ \\
\hline $\begin{array}{l}\text { Average number of family } \\
\text { members associated with } \\
\text { farming }( \pm S D)\end{array}$ & $1.33( \pm 1.1)$ & $1.39( \pm 0.52)$ & 0.03 & $\mathrm{t}=0.353^{\mathrm{NS}}(0.724)$ \\
\hline \multicolumn{5}{|l|}{ Occupation (\% farmers) } \\
\hline i) Agriculture & 74 & 58 & 16 & $\mathrm{Z}=2.388^{*}(0.016)$ \\
\hline ii) Agriculture + others & 26 & 42 & 16 & $\mathrm{Z}=2.388 *(0.016)$ \\
\hline $\begin{array}{l}\text { Average farming experience } \\
\text { (years) }\end{array}$ & $31.07( \pm 10.8)$ & $28.73( \pm 10.1)$ & 2.34 & $\mathrm{t}=1.574^{\mathrm{Ns}}(0.117)$ \\
\hline $10-23$ years (\% farmers) & 32 & 35 & 3 & \\
\hline $24-46$ years ( $\%$ farmers) & 61 & 60 & 1 & \\
\hline $47-60$ years (\% farmers) & 7 & 5 & 2 & \\
\hline
\end{tabular}

*Significant at $5 \%$ 
Table.2 Possession of farm inventory of contract and non-contract farmers

\begin{tabular}{|c|c|c|c|c|c|}
\hline \multirow[t]{2}{*}{ Assets } & \multicolumn{2}{|c|}{$\begin{array}{c}\text { Contract Farmer } \\
(\mathrm{n}=100)\end{array}$} & \multicolumn{2}{|c|}{$\begin{array}{l}\text { Non- contract Farmer } \\
(\mathbf{n}=100)\end{array}$} & \multirow[t]{2}{*}{$\underset{\text { (P-value) }}{\chi^{2}}$} \\
\hline & $\mathbf{N}$ & $\%$ & $\mathbf{N}$ & $\%$ & \\
\hline \multicolumn{6}{|l|}{ Farm Building } \\
\hline Cattle Shed & 67 & 67 & 54 & 54 & $3.53(0.06)$ \\
\hline \multicolumn{6}{|l|}{ Storage facilities } \\
\hline Store room & 65 & 65.00 & 77 & 77.00 & \multirow{2}{*}{$3.49(0.06)$} \\
\hline Storage bins & 35 & 35.00 & 23 & 23.00 & \\
\hline \multicolumn{6}{|l|}{$\begin{array}{l}\text { Milch Animals } \\
\text { (Multiple response) }\end{array}$} \\
\hline Cow & 90 & 90.00 & 80 & 80.00 & \multirow[t]{2}{*}{$33.92(0.001)$} \\
\hline Buffalo & 89 & 89.00 & 70 & 70.00 & \\
\hline \multicolumn{6}{|l|}{ Farm Implements } \\
\hline Tube well & 50 & 50.00 & 45 & 45.00 & \multirow[t]{2}{*}{$7.84 *(0.001)$} \\
\hline Pumping set & 61 & 61.00 & 38 & 38.00 & \\
\hline Tractor & 24 & 24.00 & 18 & 18.00 & \multirow[t]{7}{*}{$6.18 *(0.01)$} \\
\hline Tiller & 24 & 24.00 & 16 & 16.00 & \\
\hline Thresher & 22 & 22.00 & 18 & 18.00 & \\
\hline Trolley & 17 & 17.00 & 16 & 16.00 & \\
\hline Sprayers & 17 & 17.00 & 18 & 18.00 & \\
\hline Puddler & 20 & 20.00 & 11 & 11.00 & \\
\hline Disk-Plough & 13 & 13.00 & 5 & 5.00 & \\
\hline
\end{tabular}

*Significant at $5 \%$

Table.3 Possession of mass media by sampled farmers

\begin{tabular}{|l|c|c|c|}
\hline Mass media & $\begin{array}{c}\text { Contract Farmer } \\
(\mathbf{n = 1 0 0})\end{array}$ & $\begin{array}{c}\text { Non- contract } \\
\text { Farmer }(\mathbf{n = 1 0 0})\end{array}$ & $\begin{array}{c}\text { Absolute } \\
\text { different value }\end{array}$ \\
\hline Radio & 19 & 21 & 2 \\
\hline T.V. & 100 & 100 & 0 \\
\hline Newspaper & 24 & 13 & 11 \\
\hline
\end{tabular}

Table.4 Extent of mass media usage by sampled farmers for seeking agriculture information

\begin{tabular}{|c|c|c|c|c|c|c|}
\hline Sources & \multicolumn{2}{|c|}{ Regular } & \multicolumn{2}{|c|}{ Occasional } & \multicolumn{2}{|c|}{ Never } \\
\hline Mass Media & $\begin{array}{l}\text { Contract } \\
\text { Farmer } \\
(\mathbf{n}=\mathbf{1 0 0})\end{array}$ & $\begin{array}{c}\text { Non- } \\
\text { Contract } \\
\text { Farmer } \\
(\mathbf{n}=\mathbf{1 0 0})\end{array}$ & $\begin{array}{l}\text { Contract } \\
\text { Farmer } \\
(n=100)\end{array}$ & $\begin{array}{c}\text { Non- } \\
\text { Contract } \\
\text { Farmer } \\
(\mathbf{n}=\mathbf{1 0 0})\end{array}$ & $\begin{array}{l}\text { Contract } \\
\text { Farmer } \\
(n=100)\end{array}$ & $\begin{array}{c}\text { Non- } \\
\text { Contract } \\
\text { Farmer } \\
(\mathbf{n}=\mathbf{1 0 0})\end{array}$ \\
\hline Radio & 0 & $\begin{array}{c}8 \\
(39)\end{array}$ & $\begin{array}{c}19 \\
(\mathbf{1 0 0})\end{array}$ & $\begin{array}{c}13 \\
(\mathbf{6 1})\end{array}$ & 0 & 0 \\
\hline T.V & $\begin{array}{c}68 \\
(\mathbf{6 8})\end{array}$ & $\begin{array}{c}46 \\
(\mathbf{4 6})\end{array}$ & $\begin{array}{c}32 \\
(\mathbf{3 2})\end{array}$ & $\begin{array}{c}54 \\
(\mathbf{5 4})\end{array}$ & 0 & 0 \\
\hline Newspaper & $\begin{array}{c}8 \\
(\mathbf{3 3})\end{array}$ & $\begin{array}{c}4 \\
(31)\end{array}$ & $\begin{array}{c}16 \\
(67)\end{array}$ & $\begin{array}{c}9 \\
(69)\end{array}$ & 0 & 0 \\
\hline
\end{tabular}

Figure in parenthesis depicts percentage 
Table.5 Usage of personal contact by contract and non-contract farmers

\begin{tabular}{|c|c|c|c|c|c|c|}
\hline \multirow[b]{2}{*}{ Personal Contacts } & \multicolumn{2}{|c|}{ Regular } & \multicolumn{2}{|c|}{ Occasional } & \multicolumn{2}{|c|}{ Never } \\
\hline & $\begin{array}{l}\text { Contract } \\
\text { Farmer } \\
(\mathbf{n}=\mathbf{1 0 0})\end{array}$ & $\begin{array}{c}\text { Non- } \\
\text { Contract } \\
\text { Farmer } \\
(\mathbf{n}=\mathbf{1 0 0})\end{array}$ & $\begin{array}{l}\text { Contract } \\
\text { Farmer } \\
(n=100)\end{array}$ & $\begin{array}{c}\text { Non- } \\
\text { Contract } \\
\text { Farmer } \\
(n=100)\end{array}$ & $\begin{array}{c}\text { Contract } \\
\text { Farmer } \\
(\mathbf{n}=\mathbf{1 0 0})\end{array}$ & $\begin{array}{c}\text { Non- } \\
\text { Contract } \\
\text { Farmer } \\
(\mathbf{n}=\mathbf{1 0 0})\end{array}$ \\
\hline Department of Agriculture & 29 & 43 & 7 & 48 & 0 & 9 \\
\hline Krishi Vigyan Kendra & 21 & 20 & 79 & 41 & 0 & 39 \\
\hline Input dealers & 30 & 38 & 70 & 23 & 0 & 39 \\
\hline Contracting company & 45 & 0 & 55 & 0 & 0 & 0 \\
\hline Progressive farmers & 28 & 19 & 72 & 30 & 0 & 51 \\
\hline Friends \& Relatives & 65 & 39 & 35 & 61 & 0 & 0 \\
\hline \multicolumn{7}{|l|}{ Others } \\
\hline Training & 17 & 17 & 62 & 24 & 21 & 59 \\
\hline Group meeting & 14 & 8 & 46 & 22 & 40 & 70 \\
\hline Filed visit/tour & 6 & 0 & 74 & 28 & 20 & 72 \\
\hline Demonstration & 0 & 14 & 39 & 14 & 61 & 72 \\
\hline Exhibition & 0 & 7 & 34 & 10 & 66 & 83 \\
\hline
\end{tabular}

Table.6 Source of seed of sampled farmers (\%)

\begin{tabular}{|l|c|c|c|c|}
\multicolumn{1}{|c|}{ Source } & $\begin{array}{c}\text { Contract Farmer } \\
(\mathbf{n = 1 0 0})\end{array}$ & $\begin{array}{c}\text { Non-Contract } \\
\text { Farmer }(\mathbf{n = 1 0 0})\end{array}$ & $\begin{array}{c}\text { Difference } \\
\mathbf{\%}\end{array}$ & $\begin{array}{c}\text { Z-value } \\
(\mathbf{p}-\mathbf{1 0 l u e})\end{array}$ \\
\hline Owned & 44 & 48 & 4 & $0.568^{\mathrm{Ns}}(0.569)$ \\
\hline Company & 37 & 0 & 37 & $6.738^{*}(0.001)$ \\
\hline Input dealer & 19 & 52 & 33 & $4.877^{*}(0.001)$ \\
\hline
\end{tabular}

*Significant at $1 \%$

Farm inventory includes a complete listing of all that a farm owns and owes at a particular date, generally at the beginning and the end of each agricultural year. It includes not only the listing of physical assets but also assigning values of all such assets, liabilities and debts as well. The inventories in this study were divided into two five categories which include farm building, storerooms, milch animals, farm implements and farm machine. The result revealed that contract and non-contract farmers were statistically significant as far the assets were concerned. The number of inventories possessed by the contract farmers was more than that of the non-contract farmers.

The contract farmers were creatively well-off compared to non-contract farmers, as the contract farmers possessed higher number of different farm inventories. Velde and Maertens (2014) in their study also reported that contract farmers possessed more farm inventories as compared to non-contract farmers. The data in the table 3 reveal that all of the respondents had TV sets, yet in case of radio and newspaper the percentage was very low i.e. $19 \%$ and $24 \%$ respectively. Whereas, in case of non-contract farmers, all the respondents had TV followed by radio $(21 \%)$ and newspaper (13\%).

As 100 percent of the contract farmers had television, out of which $68 \%$ of the contract farmers were regular watchers, followed by $46 \%$ of them who were occasional watchers. A few of contract farmers read newspaper, just $33 \%$ of them read newspaper regularly and $31 \%$ of them read newspaper occasionally. In case of non-contract farmers, 
$21 \%$ of the respondents had radio, out of which $39 \%$ were regular listeners and $61 \%$ were occasional listeners. For television $46 \%$ and $54 \%$ were regular and occasional watchers respectively. But, for newspaper $31 \%$ used to read newspaper regularly, followed by $9 \%$ who used to read occasionally (Table 4).

The data in Table 5 depict that $29 \%$ of contract farmers visit agriculture department regularly, followed by $71 \%$ of the respondents who visited occasionally. Twenty one percent of the contract farmers visited Krishi Vigyan Kendra (KVK) regularly, whereas $79 \%$ of them visited occasionally. Adding more to the personal contacts, $30 \%$ of the contract farmers visited input dealer regularly and $70 \%$ occasionally, followed by contracting company (45\%) regularly and 55\% of them were occasional visitors. $28 \%$ of the contract farmer's contacted progressive farmers regularly, followed by $72 \%$ who visit occasionally. But for friends and relatives $65 \%$ of contract framers visited them regularly while $35 \%$ of them visited occasionally. Other, than the personal contacts $17 \%$ of the contract farmers regularly attended the training programme, while $62 \%$ of them occasionally attended the training programme followed by $21 \%$ who never attended any training program.

Group meetings conducted by agriculture department and contracting company, were regularly attended by $14 \%$ of the contract farmers, followed by $46 \%$ who attended the meeting occasionally, while $40 \%$ had never attended any meeting. In the event of field visit, demonstration and exhibition conducted by agriculture department, $6 \%$ and zero percent of the respondents were regular visitors respectively while, $74 \%, 39 \%$ and $34 \%$ were occasional visitors and $20 \%, 61 \%$ and $66 \%$ had never attended any project so far respectively.
In case of non-contract farmers $43 \%$ of the respondents, visited agriculture department regularly, followed by $48 \%$ who were occasional visitors. For Krishi Vigyan Kendra (KVK) $20 \%$ and $41 \%$ was regular and occasional visitors respectively, but $39 \%$ of them had never gone to Krishi Vigyan Kendra (KVK). About input dealer, 38\% visited them regularly, followed by $23 \%$ who were occasional visitors and $39 \%$ of them never went to input dealer. Nineteen percent of the non-contract farmers visited progressive farmer regularly while, $30 \%$ of them visited occasionally, but $51 \%$ of them had never visited any progressive farmer. $39 \%$ and $61 \%$ of them visited friends and relatives regularly and occasionally respectively. For training $17 \%$ of them attended training programme regularly yet $24 \%$ of them attended occasionally and 59\% had never attend any training program. In case of group meetings and field visits conducted by agriculture department just $8 \%$ of them attended the meeting regularly followed by $22 \%$ and $28 \%$ attended the meetings and visits occasionally, but $70 \%$ and $72 \%$ had never attended any meetings and visits respectively. As far as demonstration was concerned, equal percentage (14\%) was shared by the regular and occasional visitors respectively, but $72 \%$ of them had never attended any demonstration programme. In case of exhibition $7 \%$ and $10 \%$ of the non-contract farmers were regular and occasional visitors, but $83 \%$ of them stated that they had never attended any exhibition (Table 5).

The different sources which were reported by contract farmers were contract company, domestic seeds and input dealer. Out of the listed sources majority (44\%) of the contract farmers used domestic seeds followed by $37 \%$ who purchased the seed from contracting firm and input dealer as a source was opted by $19 \%$ of the contract farmers. Whereas, in case of non-contract farmers, majority (52\%) of 
respondents purchased seeds from input dealer while $48 \%$ of them used domestic seeds. The difference between the sources of seeds among contract and non-contract farmers was statistically significant on account of contract company and input dealer but non-significant in the case of domestic seed (Table 6).

It was concluded from the study that young farmers are motivated to go for contract farming as majority of the contract farmers were of middle age-group. Contract farming creates the win-win situations for farmers and were more interested in doing farming as it was found that contract farmers possessed more farm inventories as compared to noncontract farmers. There must be regular training programmes, group meetings, demonstration and exhibitions regarding benefits and procedures of contract farming.

\section{References}

Arumugam, Nalini and Shamsudin, Mohd Annas Bin. 2013. Attitudes of Rock Melon Growers' towards Contract
Farming Practices. Proceeding of the International Conference on Social Science Research, ICSSR 2013 (e-ISBN 978-967- 11768-1-8).4-5 June 2013, Penang, MALAYSIA. Organized by World Conferences.net.

Pandit, Arun, Pandey. N.K., K. Rana Rajesh and Lal. Barsati. 2009. An Empirical Study of Gains from Potato Contract Farming. Indian Journal of Agriculture Economics. Vol.64, No.3, July-Sept. 2009.

Roy, E.P. 1963. Contract farming - USA, The Interstate Printers and Publishers, Inc. Danville, Illinois, USA.

Sharma, V.P. 2008. India's Agrarian Crisis and Corporate-Led Contract Farming: Socio-Economic Implications for Smallholder Producers. International Food and Agribusiness Management Review, 11(4): 25-48.

Velde, V.K. and Maertens Miet. 2014. Contract-farming in staple food chains: the case of rice in Benin. Bioeconomics Working Paper Series Working Paper 2014/9.

\section{How to cite this article:}

Parvani Sharma, Rakesh Nanda and Yudhishther Singh Bagal. 2018. A Comparative Study on Socio-Personal and Economic Profile of Contract Farmers and Non-Contract Farmers in Jammu. Int.J.Curr.Microbiol.App.Sci. 7(08): 722-729.

doi: https://doi.org/10.20546/ijcmas.2018.708.079 